\title{
PEROLEHAN KEMBALI STATUS KEWARGANEGARAAN YANG HILANG BERDASARKAN UNDANG-UNDANG KEWARGANEGARAAN
}

\author{
Emmy Wulandari \\ wulandariemmy92@gmail.com \\ Fakultas Hukum Universitas Airlangga
}

\begin{abstract}
Absract
In the democratic state and the rule of law, human rights protection is an essential principle. The fact that citizenship status is fundamental rights put consequences that the states and citizen has reciprocal relations which means states needs their citizens as well as citizens need states. States should ensure that no one in the states is left stateless. In order to avoid stateless, the State needs to be aware and anticipative which is reflected through legislation and administrative practices. In the Heidy Mariska case, the administrates neglected article 17c Law No. 62 Year 1958 on Citizenship which then results in diffusion of Heidy Mariska citizenship status so that she was stateless in the country she was born in. This paper analyse the implementation of the law on citizenship whether or not it reflects protection to citizenship status and anticipation of statelessness.
\end{abstract}

Keywords : citizenship, human rights, recovery.

\begin{abstract}
Abstrak
Perlindungan Hak Asasi Manusia (HAM) merupakan syarat mutlak dalam Negara Hukum. Perlindungan HAM oleh Negara diwujudkan salah satunya melalui pembentukan peraturan perundang-undangan yang berarti menunjukkan kesungguhan Pemerintah memberikan jaminan pada warga Negara. Status kewarganegaraan adalah HAM, artinya bahwa tidak boleh ada seorangpun yang tidak memiliki status kewarganegaraan (stateless) maka, bentuk antisipasi Negara terhadap kemungkinan ini adalah segala perangkat hukum dan administratif yang menjadi solusi bagi warga Negara ketika warga Negara tersebut dihadapkan pada persoalan yang khusus seperti: pernikahan dengan warga asing, status kewarganegaraan bagi anak luar kawin, dsb. Kasus Heidy Mariska yang disoroti dalam artikel ini menunjukkan kelalaian pejabat administratif pada penerapan ketentuan Pasal 17 huruf (c) Undang-Undang No. 62 Tahun 1958. Artikel ini menganalisis aturan-aturan hukum yang dapat diterapkan pada kasus sehingga dapat diketahui apakah peraturan perundang-undangan yang ada telah cukup memberikan perlindungan HAM terhadap status kewarganegaraan Indonesia yang dimilikinya sehingga seseorang dapat memperoleh kembali status kewarganegaraannya.
\end{abstract}

Kata Kunci : kewarganegaraan, hak asasi, perolehan kembali 


\section{Pendahuluan}

Salah satu hak yang yang harus dipenuhi negara terhadap warga negaranya adalah status kewarganegaraan. Status kewarganegaraan seseorang menjadi hak dasar warga negara yang harus dipenuhi, dihargai, dihormati, dan dilindungi oleh negara. Indonesia telah mengatur bahwa status kewarganegaraan merupakan hak dasar setiap orang pada Undang-Undang Dasar Negara Republik Indonesia 1945 yang selanjutnya disebut UUD 1945 Pasal 28 D ayat (4).

Artikel yang merupakan bagian tugas akhir ini menganalisa atas apa yang terjadi pada Heidy Mariska yang saat ini berstatus tanpa kewarganegaraan (apatride). Heidy Mariska saat ini adalah seorang yang tanpa kewarganegaraan di tanah kelahirannya sendiri, Indonesia. Heidy Mariska adalah anak Ny. Soe Tin yang menikah dengan pria berkewarganegaraan Belanda secara agama (Islam).

Pernikahan tersebut kemudian di daftarkan di Kantor Catatan Sipil Malang. Ibu Heidy Mariska sudah bercerai dengan warga negara Belanda tersebut pada saat pembuatan akta kelahiran Heidy Mariska. Sehingga, akta kelahiran Heidy Mariska menyatakan jika Heidy Mariska adalah putri dari seorang Warga Negara Indonesia. Tetapi Ibu Heidy Mariska (Ny. Soe Tin) berupaya membuktikan jika Heidy Mariska adalah anak Warga Negara Belanda dengan pengakuan dari sang ayah melalui akta Notaris Chusen Bisri Malang, yang kemudian ditetapkan oleh Pengadilan Negeri Malang.

Berdasarkan Penetapan Pengadilan Negeri Malang Nomor 331/Pdt.P/2001/PN.Mlg tertanggal 14 Januari 2002, mengabulkan permohonan pengakuan anak luar kawin dan perubahan akta kelahiran atas nama Heidy Mariska. Pada saat itu Heidy Mariska berusia 18 (delapan belas) tahun. Penetapan Pengadilan Negeri Malang tersebut telah berkekuatan hukum tetap. Atas dasar Penetapan Pengadilan Negeri Malang tersebut, Kepala Dinas Kependudukan Kota Malang pada tanggal 26 Januari 2002 melakukan perubahan terhadap akta kelahiran atas nama Heidy Mariska, yang melalui catatan pinggir menyatakan Heidy Mariska adalah Warga Negara Belanda.

Sampai saat ini kasus ini belum menemukan jalan keluar untuk status kewarganegaraan dari Heidy Mariska. Heidy Mariska mengajukan permohonan menjadi Warga Negara Belanda sejak Maret 2008. Permohonan tersebut disampaikan melalui Kantor Konsulat Belanda. Sampai bulan September 2013 permohonan Heidy Mariska untuk menjadi Warga Negara Belanda ternyata tidak diterima oleh Pemerintah Belanda melalui Konsulat Jenderal di Surabaya.

Mengacu pada Keputusan Pengadilan Den Haag Nomor C/09/424604/HA RK 12-436 tertanggal 25 April 2013, Negara Belanda memutuskan menolak permohonan kewarganageraan Belanda atas nama Heidy Mariska. Pernikahan kedua orang tuanya yang dilakukan secara agama (Islam) tidak mempunyai kekuatan hukum dengan pencatatan akta di Kantor Catatan Sipil. Sehingga anak dari pernikahan tersebut yakni Heidy Mariska tidak dapat diakui secara hukum Belanda. Heidy Mariska statusnya menjadi tanpa kewarganegaraan (apatride) saat ini. Undang-Undang Nomor 12 Tahun 2006 sangat melindungi status kewarganegaraan seseorang. 


\section{Kehilangan Status Kewarganegaraan}

Hak Asasi Manusia sebagai anugerah Tuhan Yang Maha Esa. Hak Asasi Manusia pada hakikatnya merupakan refleksi dari eksistensi manusia. Melalui kesadaran universal lahirlah apresiasi positif terhadap nasib dan masa depan komunitas manusia. HAM adalah formasi keutuhan manusia menuju kehidupan yang beradab. Merujuk pada pengertian Hak Asasi Manusia dalam Undang-Undang No. 39 Tahun 1999 tentang Hak Asasi Manusia Pasal 1 angka 1 memberikan rumusan tentang pengertian Hak Asasi Manusia sebagai Seperangkat hak yang melekat pada hakikat dan keberadaan manusia sebagai makhluk Tuhan Yang Maha Esa dan merupakan anugerah-Nya yang wajib dihormati, dijunjung tinggi dan dilindungi oleh negara, hukum, pemerintah, dan setiap orang demi kehormatan serta perlindungan harkat dan martabat manusia.

Nurul Qamar berpendapat, “ jika HAM merupakan hak yang diperoleh setiap manusia sebagai konsekuensi ia ditakdirkan Ilahi sebagai manusia, maka lain halnya dengan hak dasar, sebagai suatu hak yang diperoleh setiap manusia sebagai konsekuensi ia menjadi warga negara dari suatu negara." ${ }^{1}$ Dilihat dari sumbernya, HAM berasal dari Tuhan sedangkan hak dasar berasal dari negara atau pemerintah. HAM bersifat universal, sedangkan hak dasar bersifat terbatas. Secara Filosofi HAM adalah kebebasan yang menitikberatkan pada penghormatan terhadap kebebasan orang lain. Artinya, kebebasan HAM terbatas, ketika kebebasan tersebut berhimpitan dengan kebebasan orang lain.

Status kewarganegaraan adalah hak dasar bagi seseorang. Status kewarganegaraan menimbulkan hak dan kewajiban bagi pemiliknya. Seorang warga negara mempunyai hubungan timbal balik antara negara dan warga negaranya. Negara wajib menjamin kepemilikan hak seorang warga negaranya yang mencakup hak sipil, hak politik, hak ekonomi, sosial, dan budaya. Sedangkan kewajiban sebagai seorang pemegang status kewarganegaraan Indonesia telah ditetapkan di dalam UUD 1945.

Menurut Mahfud MD, bahwa setiap warga negara mempunyai kewajiban-kewajiban konstitusional baik sebagai Warga Negara Indonesia maupun sebagai manusia. Sebagai warga negara mereka dituntut untuk memiliki rasa kebangsaan (nasionalisme) atau rasa cinta terhadap tanah air sehingga harus siap membela dan berkorban demi kelangsungannya. Dengan demikian ada prestasi timbal balik antara perlindungan atas hak-hak yang diberikan oleh negara serta kesediaan untuk berkorban bagi kelangsungan bangsa dan negara. ${ }^{2}$

Pengaturan status kewarganegaraan sebagai Hak Asasi Manusia diatur dalam beberapa instrumen internasional, yakni Deklarasi Universal Hak Asasi Manusia (1948)². Deklarasi Universal Hak Asasi Manusia menjadi landasan penegakan dan penghormatan terhadap HAM secara universal. Pengesahan DUHAM juga menjadi landasan terbentuknya dua kovenan

\footnotetext{
1 Nurul Qamar, Hak Asasi Manusia dalam Negara Hukum Demokrasi, Sinar Grafika, Jakarta, 2013, h.17 2 Mahfud MD, Makalah Sosialisasi UU No.12 Tahun 2006 tentang Kewarganegaraan,

3 Deklarasi Universal Hak Asasi Manusia ditetapkan oleh Majelis Umum Perserikatan Bangsa-Bangsa dalam resolusi No. 217 A (III) pada tanggal 10 Desember 1948.
} 
internasional yang berpengaruh terhadap penegakan HAM. Latar belakang lahirnya DUHAM salah satunya adalah dampak yang terjadi pada Perang Dunia II. Sehingga, PBB sebagai organisasi yang bersifat universal menganggap perlunya sebuah intsrumen internasional yang mengatur tentang penegakan HAM. Hak dan kebebasan yang tercantum dalam DUHAM mencakup sekumpulan hak yang lengkap, baik hak sipil, politik, budaya, ekonomi, dan sosial setiap individu.

Dalam hubungannya dengan status kewarganegaraan sebagai HAM, DUHAM mengatur secara jelas mengenai status kewarganegaraan pada setiap manusia. Dinyatakan dalam Pasal 15 ayat (1) bahwa," seseorang berhak atas suatu status kewarganegaraan". Sedangkan ayat (2) menyatakan bahwa "tidak berhak seseorang pun dicabut status kewarganegaraannya dan mengingkari hak untuk mengubah kewarganegaraan".

Status kewarganegaraan sebagai HAM juga diatur dalam Kovenan Internasional tentang Hak Sipil dan Politik (1966) ${ }^{4}$ International Covenant on Civil and Political Rights atau biasa disebut ICCPR bertujuan untuk memperkuat pokok-pokok HAM dalam bidang Sipil dan politik yang tercantum dalam DUHAM sehingga menjadi ketentuan-ketentuan yang mengikat secara hukum. Dalam kovenan hak sipil dan politik tidak memberikan definisi secara jelas pengertian hak sipil dan politik. Tetapi ada klasifikasi hak yang bersifat hak sipil dan hak politik. Dari beberapa pasal yang mengatur mengenai hak sipil dan politik dapat ditarik perbedaan pengertian tentang hak sipil dan hak politik. Hak sipil adalah hak yang hak fundamnetal yang diperoleh sebagai hakikat keberadaan seorang manusia. Sedangkan hak politik adalah hak dasar yang bersifat mutlak dalam setiap warga negara yang harus dijunjung tinggi, dihormati dan dipenuhi oleh negara sebagai bentuk tanggung jawab negara. Jika demikian, status kewarganegaraan merupakan hak politik yang dimiliki oleh setiap warga negara. Dalam Pasal 24 ayat (3) diterangkan bahwa, setiap anak berhak untuk memeproleh kewarganegaraan.

Konvensi Internasional Penghapusan Segala Bentuk Diskriminasi Rasial (1965) Konvensi Internasional Penghapusan Segala Bentuk Diskriminasi Rasial atau yang lebih dikenal dengan ICERD (International Convention on the Elimination of All Forms of Racial Discrimination) adalah sebuah instrumen hukum internasional yang mengatur tentang penghapusan diskriminasi rasial. Secara garis besar, ICERD mewajibkan negara-negara pihak untuk menghapuskan berbagai bentuk dan perwujudan dari diskriminasi ras di negaranya serta menjamin hak-hak setiap orang tanpa membedakan ras, warna kulit, keturunan, asal-usul

4 Majelis Umum PBB melalui Resolusi No. 2200 A (XXI) mengesahkan Kovenan Internasional tentang Hak-hak Sipil dan Politik (ICCPR) dan Opsional Protokol Kovenan Internasional tentang Hak Sipil dan Politik secara bersama-sama pada 16 Desember 1966 dan berlaku pada 23 Maret 1976.tentang Pengesahan ICCPR.

5 Pada 21 Desember 1965 Majelis Umum PBB mengesahkan ICERD ini sebagai resolusi 2106 A (XX) dan mulai berlaku secara efektif pada 4 Januari 1969. Indonesia melakukan Ratifikasi terhadap ICERD melalui Undang-Undang No. 29 Tahun 1999 dengan reservasi (persyaratan) terhadap Pasal 22 konvensi ICERD dimana Indonesia menyatakan, "Pemerintah Republik Indonesia menyatakan tidak terikat pada ketentuan Pasal 22 Konvensi Internasional tentang Penghapusan Segala Bentuk Diskriminasi Rasial 1965 dan berpendirian bahwa apabila terjadi persengketaan akibat perbedaan penafsiran atau penerapan isiniya yang tidak terselesaikan melalui saluran sebagaimana diatur dalam pasal tersebut, dapat menunjuk Mahkamah Internasional hanya berdasarkan kesepakatan para pihak yang bersengketa." 
kebangsaan atau etnis di dalam hukum terutama kesempatan untuk mempergunakan hak-hak yang dimiliki. Dalam hubungannya dengan status kewargnegaraan yang dimiliki seseorang, ICERD menjamin untuk tidak membeda-bedakan status kewarganegaraan yang dimiliki oleh setiap orang. Diterangkan dalam pasal 5 huruf d romawi (iii) yang menyatakan bahwa, "untuk memenuhi kewajiban-kewajiban dasar yang dicantumkan dalam Pasal 2 Konvensi ini, negaranegara pihak melarang dan menghapuskan segala bentuk diskriminasi ras serta menajmin hak setiap orang tanpa membedakan ras, warna kulit, asal bangsa dan suku bangsa, untuk diperlakukan sama di depan hukum, terutama untuk menikmati hak di bawah ini, hak sipil lainnya, khusunya hak untuk memiliki kewarganegaraan.

Konvensi Internasional mengenai Penghapusan Segala Bentuk Diskriminasi terhadap Perempuan (1979) ${ }^{6}$; Convention on the Elimination of All forms od Discrimination Againts Women (CEDAW) menetapkan secara universal prinsip-prinsip persamaan hak antara laki-laki dan perempuan terlepas dari status perkawinan mereka, disemua bidang sipil, politik, ekonomi, sosial, dan budaya. CEDAW mendorong diberlakukannya perundang-undangan secara nasional yang melarang diskriminasi dan memberlakukan tindakan-tindakan khusus untuk melaksanakan kesetaraan laki-laki dan perempuan.

Status kewarganegaraan yang merupakan hak sipil bagi setiap orang tidak terkecuali perempuan juga diatur dalam CEDAW. Diterangkan dalam Pasal 9 ayat (1) yang menyatakan bahwa, "negara-negara pihak wajib memberikan kepada perempuan hak yang sama dengan laki-laki untuk memperoleh, mengubah atau mempertahankan kewarganegaraanya. Negaranegara pihak khususnya wajib menjamin bahwa baik perkawinan dengan orang asing maupun perubahan kewarganegaraan oleh suami selama perkawinan, tidak secara otomatis mengubah kewarganegaraan istri, menjadikannya tidak berkewarganegaraan atau memaksakan kewarganegaraan suami kepadanya. Sedangkan ayat (2) menyatakan bahwa negara-negara pihak wajib memberikan kepada perempuan hak yang sama dengan laki-laki berkenaan dengan kewarganegaraan anak-anak mereka.

Konvensi tentang Hak - Hak Anak (1989) ${ }^{7}$; Convention on the Right sof The Child memberikan perlindungan terhadap hak yang dimiliki oleh setiap anak. Konvensi Hak-Hak Anak mempunyau dua protokol opsional yaitu pertama, Protokol Opsional Konvensi Hak-Hak Anak mengenai Keterlibatan Anak dalam Konflik Bersenjata yang telah diratifikasi Indonesia melalui Undang-Undang No.9 Tahun 2012. Kedua, Protokol Opsional Konvensi Hak-Hak Anak mengenai Penjualan Anak, Prostitusi Anak dan Pornografi Anak (telah diratifikasi Indonesia melalui Undang-Undang No.10 Tahun 2012). Status kewarganegaraan diatur dalam Konvensi ini dalam Pasal 7 ayat (1) yang menyatakan bahwa, "anak harus didaftarkan

6 CEDAW disahkan melalui Resolusi Majelis Umum PBB 34/180 tertanggal 18 Desember 1979 dna mulai berlaku pada 3 September 1981. Indonesia meratifikasi CEDAW melalui Undang-Undang No. 7 Tahun 1984 tentang Pengesahan Konvensi Mengenai Pengahpusan Segala Bentuk Diskriminasi terhadap Wanita.

7 Konvensi tentang Hak-Hak Anak disahkan pada tanggal 20 November 1989 dan mulai berlaku secara efektif pada tanggal 2 September 1990. Indonesia telah meratifikasi Konvensi tentang Hak-Hak Anak dengan Keputusan Presiden No. 36 Tahun 1996. 
segera sesudah kelahiran dan harus mempunyai hak sejak lahir atas suatu nama, hak untuk memperoleh kewarganegaraan dan sejauh mungkin hak untuk mengetahui dan dirawat oleh orang tuanya. Dalam ayat (2) bahwa negara-negara pihak harus menjamin pelaksanaan hak-hak ini sesuai dengan hukum nasional mereka dan kewajiban mereka menurut instrumen-instrumen internasional yang relevan dalam bidang ini, terutama apabila anak sebaliknya akan tidak berkewarganegaran.

Negara Indonesia yang menganut sistem politik bebas-aktif juga ikut melaksanakan instrumen internasional tersebut ke dalam hukum nasional Indonesia. UUD 1945 sebagai konstitusi negara Indonesia secara tegas mengatur tentang Hak Asasi Manusia. Nilai dan prinsip HAM dalam UUD 1945 dikembangkan dalam produk legislasi hukum dan peraturan dalam segala bidang. Baik berupa undang-undang khusus yang mengatur tentang HAM seperti Undang-Undang No. 39 Tahun 1999, maupun pengaturan di bidang yang lain. Pengaturan tentang HAM utamanya UUD NRI 1945 beserta perubahannya.. Status kewarganegaraan merupakan hak konstitusional yang tertuang dalam Undang-Undang Dasar Negara Republik Indonesia Tahun 1945 Pasal 28D ayat (3) yang menyatakan bahwa "setiap orang berhak atas status kewarganegaraan.

UU No. 39 Tahun 1999 tentang Hak Asasi Manusia. Undang-undang ini dibentuk setelah amandemen pertama UUD 1945. Perubahan konstitusi tersebut mencantumkan HAM dalam konstitusi negara Indonesia. Kemudian dibentuk undang-undang tentang HAM dengan tujuan pengaturan khusu mengenai HAM setelah dituangkan dalam batang tubuh konstitusi negara Indonesia. Diterangkan dalam Pasal 26 ayat (1) bahwa, "setiap orang berhak memiliki, memperoleh, mengganti atau mempertahankan status kewarganegaraannya. Kemudian dalam ayat (2) bahwa setiap orang bebas memilih kewarganegaraannya dan tanpa diskriminasi berhak menikmati hak-hak yang bersumber dan melekat pada kewarganegaraannya serta wajib melaksanakan kewajibannya sebagai warga negara sesuai dengan ketentuan peraturan perundang-undangan. Tercantum dalam Pasal 47 dan Pasal 53 ayat (2). UU No. 23 Tahun 2002 tentang Perlindungan Anak. Undang-Undang Perlindungan Anak juga mengatur ketentuan bahwa status kewarganegaraan sebagai hak yang dimiliki seorang anak. Dalam Pasal 5 yang menyatakan bahwa, setiap anak berhak atas suatu nama sebagai identitas diri dan status kewarganegaraan.

Undang-Undang No.12Tahun2006mengaturkeseluruhantentangstatuskewarganegaraan Republik Indonesia. Siapa saja yang menjadi Warga Negara Indonesia yang memiliki kewarganegaraan Indonesia diatur dalam undang-undang ini. Juga diterangkan pula dalam Pasal 8 ayat (1) yang menyatakan bahwa, negara-negara pihak harus berusaha menghormati hak anak untuk mempertahankan identitasnya, termasuk kewarganegaraan, nama dan hubungan kelaurga seperti yang diakui oleh hukum tanpa campur tangan yang tidak sah. Ayat (2) pasal yang sama menyatakan jika seorang anak secara tidak sah dicabut beberapa atau semua unsur identitasnya, maka negara-negara pihak harus memberikan bantuan dan perlindungan yang tepat dengan 
tujuan secara cepat membentuk kembali identitasnya. Hilangnya kewarganegaraan seseorang berarti hilangnya hak dan kewajiban orang itu terhadap negara yang bersangkutan. Hilangnya status kewarganegaraan seseorang mengakibatkan putusnya hubungan seorang warga negara dengan negaranya. Ada beberapa penyebab seseorang kehilangan kewarganegaraa, antara lain:

Renunciation, yaitu tindakan sukarela untuk meninggalkan salah satu dari dua atau lebih status kewarganegaraan yang dimiliki dari dua negara atau lebih.Termination, yaitu penghentian status kewarganegaraan sebagai tindakan hukum karena yang bersangkutan telah memiliki kewarganegaraan dari negara lain. Deprivation, yaitu pencabutan atau penghentian secara paksa atau pemecatan status kewarganegaraan berdasarkan perintah pejabat yang berwenang karena terbutki adanya kesalahan atau pelanggaran dalam memperoleh status kewarganegaraan. ${ }^{8}$

Hilangnya kewarganegaraan seseorang dapat juga dikarenakan kelalaian, karena alasan politik karena alasan teknis ataupun karena alasan yang bersangkutan memang secara sadar dan sengaja ingin melepaskan status kewarganegaraannya. ${ }^{9}$ Beberapa alasan tersebut hendaknya dijadikan pertimbangan apabila yang bersangkutan di kemudian hari ingin memperoleh kewarganegaraannya kembali. Proses perolehan kembali yang dilakukan untuk masing-masing alasan tersebut harusnya berbeda satu sama lain. Pada pokoknya adalah setiap orang terjamin haknya untuk mendapatkan status kewarganegaraan, sehingga terhindar dari kemungkinan stateless, apatride atau tanpa kewarganegaraan.

Heidy Mariska secara sukarela mengajukan permohonan menjadi Warga Negara Belanda seperti yang dimiliki oleh sang ayah. Pemerintah Indonesia melalui Pengadilan Negeri Malang mengabulkan permohonan tersebut dengan kemudian menyatakan bahwa Heidy Mariska bukan lagi Warga Negara Indonesia melainkan Warga Negara Belanda.

Pada saat Heidy Mariska dinyatakan kehilangan kewarganegaraan Indonesia oleh Pengadilan Negeri Malang tahun 2001, Hakim Pengadilan Negeri Malang menggunakan ketentuan Pasal 17 huruf (c) Undang-Undang No. 62 Tahun 1958, yang menyatakan bahwa kewarganegaraan Indonesia hilang karena diakui oleh orang asing sebagai anaknya, jika orang yang bersangkutan belum berumur 18 tahun dan belum kawin dan dengan kehilangan kewarganegaraan Republik Indonesia tidak menjadikan tanpa kewarganegaraan. Pasal tersebut mengatur mengenai pengakuan anak luar kawin oleh orang asing. Ayah kandung Heidy Mariska yang seorang Warga Negara Belanda mengakui Heidy Mariska sebagai anaknya. Tetapi ketentuan lain yang kurang diperhatikan oleh Hakim pada saat itu adalah jika anak yang bersangkutan belum berumur 18 tahun dan belum kawin.

Fakta yang terjadi adalah pada saat pengakuan anak tersebut dan dikuatkan dengan akta Notaris Chusen Bisri (Malang), Heidy Mariska sudah berumur 18 (delapan belas) tahun. Jika demikian, ketentuan Pasal 17 huruf (c) tersebut sudah tidak dapat diberlakukan terhadap Heidy Mariska yang sudah berumur 18 (delapan belas) tahun.

8 Jimly Asshiddiqie, Pengantar Ilmu Hukum Tata Negara Jilid II, Sekretaris Jenderal dan Kepaniteraan Mahkamah Konstitusi, Jakarta, 2006, h. 112

9 Ibid, h. 152 
Kesalahan pejabat yang berwenang pada saat itu selain kurang hati-hati menggunakan ketentuan perundangan adalah tidak ada konfirmasi penerimaan menjadi Warga Negara Belanda dari Kantor Perwakilan Negara Belanda atas permohonan pewarganegaraan Belanda atas nama Heidy Mariska. Sebagaimana di negara Indonesia permohonan pengajuan pewarganegaraan negara Belanda semestinya juga harus dilengkapi dengan syarat-syarat dengan menunjukkan dokumen-dokumen sebagai bukti untuk menguatkan pengajuan pewarganegaraan. Pengajuan pewarganegaraan tersebut haruslah mendapat kepastian terlebih dahulu, diterima sebagai Warga Negara Belanda atau ditolak sebagai Warga Negara Belanda. Heidy Mariska belum menerima keputusan apapun dari perwakilan Negara Belanda di Indonesia, namun Hediy Mariska sudah dinyatakan oleh Pengadilan Negeri Malang bahwa ia telah kehilangan kewarganegaraan Indonesia. Hal ini mengakibatkan Heidy Mariska menjadi seorang stateless atau apatride.

\section{Perolehan Kembali Status Kewarganegaraan}

Kehilangan Kewarganegaraan Indonesia yang dialami oleh Heidy Mariska harus segera dikembalikan oleh negara sebagai bentuk tanggung jawab negara atas pemenuhan hak asasi. Pemenuhan status kewarganeraan sebagai hak Heidy Mariska merupakan bentuk tanggung jawab negara terhadap Pasal 28 D ayat (4) UUD NRI 1945, yang menyatakan bahwa status kewarganegaraan merupakan hak setiap orang. Sebagai seorang anak yang terlahir dari Warga Negara Indonesia, Heidy Mariska mempunyai hak asasi yang belum dipenuhi oleh Negara Indonesia. Heidy Mariska memiliki hak mempunyai status kewarganegaraan seperti yang tertera dalam instrumen hukum internasional dan hukum nasional tersebut. Heidy Mariska berhak untuk memperoleh status kewarganegaraan yang jelas karena Negara Indonesia bertanggung jawab memenuhi hak asasi warga negaranya. Pertanggung jawaban Negara Indonesia diawali dengan meratifikasi instrumen hukum internasional yang mengatur mengenai perlindungan hak asasi, yang kemudian ditindak lanjuti oleh pemerintah Indonesia dengan membentuk peraturan perundang-undangan yang merupakan implementasi dari hukum internasional yang diratifikasi.

Salah satu peraturan perundang-undangan adalah Undang-Undang No. 12 Tahun 2006 tentang Kewarganegaraan Republik Indonesia. Tertulis jelas dalam Penjelasan UndangUndang No. 12 Tahun 2006 bahwa," bahwa undang-undang ini pada dasarnya tidak mengenal kewarganegaraan ganda (bipatride) ataupun tanpa kewarganegaraan (apatride). Selain itu pula, dalam Penjelasan Undang-Undang No. 12 Tahun 2006 salah satu asas khusus yang mendasari penyusunan undang-undang ini adalah asas pengakuan dan penghormatan terhadap hak asasi manusia. Asas tersebut adalah asas yang dalam segala hal ihwal yang berhubungan dengan warga negara harus menjamin, melindungi, dan memuliakan hak asasi manusia pada umumnya dan hak warga negara pada khususnya." Maka sebagai perwujudan pelaksanaan undang-undang tersebut, status kewarganegaran sebagai hak asasi dari Heidy Mariska yang hilang harus segera dikembalikan sebagai pemenuhan tanggung jawab Negara Indonesia. Selain itu, Penetapan Pengadilan Negeri Malang Nomor 331/Pdt.P/2001/PN.Mlg merupakan Keputusan Tata Usaha 
Negara (KTUN). Pengadilan dapat saja melakukan penetapan yang masuk dalam lingkup urusan pemerintahan. Urusan pemerintahan adalah kegiatan yang bersifat eksekutif. KTUN selain sebagai keputusan pelaksanaan juga merupakan keputusan bebas.

Menurut P. M. Hadjon, pengertian pejabat/badan TUN janganlah diartikan semata-mata secara struktural tetapi lebih ditekankan pada aspek fungsional. Jika suatu badan/pejabat negara menerbitkan suatu penetapan yang secara fungsional merupakan lingkup urusan pemerintahan, maka dapat diartikan badan/pejabat negara tersebut mengeluarkan KTUN. Aspek fungsional dari KTUN ditekankan pada adanya tindakan hukum publik. ${ }^{10}$ Jika penetapan merupakan KTUN, maka upaya yang dapat dilakukan Heidy Mariska adalah permohonan pembatalan KTUN. Pengajuan pembatalan KTUN dapat dilakukan Heidy Mariska dengan alasan hak konstitusional Heidy Mariska dicabut dengan terbitnya KTUN tersebut. Perubahan KTUN dapat diupayakan dengan alasan ${ }^{11}$ :Adanya perubahan kondisi tertentu; Pemberian informasi atau keterangan palsu, Indikasi kelalaian yang dilakukan pejabat; Pelanggaran ketentuan akibat adanya KTUN

Heidy Mariska dapat melakukan upaya tersebut dengan alasan perubahan kondisi. Perubahan kondisi tersebut adalah perubahan ketentuan perundang-undangan tentang kewarganegaraan. Perubahan undang-undang dari Undang-Undang Nomor 62 Tahun 1958 diubah menjadi Undang-Undang Nomor 12 Tahun 2006. Penetapan Pengadilan yang menyatakan bahwa Heidy Mariska kehilangan kewarganegaraan Indonesia terjadi pada saat berlakunya Undang-Undang Nomor 62 Tahun 1958. Kemudian penolakan oleh Negara Belanda terjadi pada saat Undang-Undang Nomor 12 Tahun 2006 sudah berlaku. Maka selama rentang waktu yang cukup lama Heidy menyandang status tanpa kewarganegaraan. Untuk itu, diperlukan tindakan dari negara untuk status Heidy Mariska yang tanpa kewarganegaraan karena bertentangan dengan tujuan dibentuknya Undang-Undang tentang Kewarganegaraan Republik Indonesia. Perlindungan yang diberikan dengan cara mengembalikan status Kewarganegaraan Republik Indonesia kepada Heidy Mariska. Perlindungan tersebut juga akan memberikan kepastian kepada Heidy Mariska yang diakui sebagai Warga Negara Indonesia. Status tanpa kewarganegaraan (apatride) membuat Heidy tidak memiliki suatu dokumen yang menunjukkan bahwa Heidy adalah Warga Negara Indonesia atau Warga Negara Belanda.

Dalam Undang-Undang No. 23 tahun 2006 tentang Administrasi Kependudukan, diatur mengenai pentingnya seseorang memiliki Nomor Induk Kependudukan dan Kartu Tanda Penduduk. Pasal 1 angka 12 undang-Undang No.23 2006 menyatakan bahwa Nomor Induk Kependudukan adalah nomor identitas Penduduk yang bersifat unik atau khas, tunggal dan melekat pada seseorang yang terdaftar sebagai penduduk Indonesia. Kemudian dalam Pasal 1 angka 14 menyatakan bahwa Kartu Tanda Penduduk adalah identitas resmi Penduduk sebagai bukti diri yang diterbitkan oleh instansi pelaksana yang berlaku di seluruh wilayah Negara

10 Philipus M. Hadjon, Pengantar Hukum Administrasi Indonesia, Gadjah Mada University Press, Yogyakarta, 2005, h.139

11 Ibid 
Kesatuan Republik Indonesia. Sebagai orang yang tanpa kewarganegaraan Heidy tidak memiliki NIK maupun KTP. Padahal dalam Pasal 13 ayat (1) Undang-Undang No. 23 Tahun 2006 bahwa, "Setiap penduduk wajib memiliki NIK". Sehingga keberadaan Heidy Mariska juga sangat dibatasi dengan adanya penerapan Undang-Undang No. 6 Tahun 2011 tentang Keimigrasian. Untuk itu, diperlukan pengaturan khusus untuk memulihkan status Kewarganegaraan Indonesia atas Heidy Mariska. Perolehan kembali Kewarganegaraan Republik Indonesia tersebut bukan perolehan kembali sesuai prosedur biasa yang terdapat dalam Bab V tentang Syarat dan Tata Cara Memperoleh Kembali Kewarganegaraan Republik Indonesia Undang-Undang No. 12 Tahun 2006.

Prosedur perolehan kembali yang ditetapkan mensyaratkan bahwa yang bersangkutan harus memiliki dokumen-dokumen pelengkap yang telah ditetapkan. Heidy Mariska tidak akan dapat memenuhi persyaratan yang ditetapkan karena tidak memilik dokumen-dokumen yang dimaksud untuk memperoleh kembali Kewarganegaraan Indonesia dikarenakan Heidy belum mengalami satupun peristiwa Kependudukan. Misalnya, bertempat tiggal di luar negeri ataupun dokumen pernikahan. Seperti yang telah dijelaskan dalam Bab II skripsi ini, bahwa kehilangan status kewarganegaraan yang dialami Heidy Mariska karena ketidakhati-hatian pejabat yang berwenang saat itu, sehingga perolehan kembali status kewarganegaraan Heidy Mariska dengan pengaturan khusus tanpa melalui prosedur yang ditetapkan peraturan perundang-undangan.

\section{Kesimpulan}

Kehilangan kewarganegaraan yang terjadi pada Heidy Mariska dikarenakan kelalaian pada penerapan ketentuan Pasal 17 huruf (c) Undang-Undang No. 62 Tahun 1958 yang menyatakan bahwa seorang anak yang belum berumur 18 (delapan belas) tahun diakui oleh orang asing sebagai anaknya akan kehilangan Kewarganegaraan Indonesia. Ketentuan tersebut dapat diberlakukan dengan syarat anak yang bersangkutan belum berumur 18 (delapan belas) tahun atau belum kawin. Pada saat Undang-Undang tersebut diberlakukan Heidy Mariska telah berumur 18 (delapan tahun). Perlu dibuat ketentuan khusus, yakni Keputusan Tata Usaha Negara (KTUN) yang bersifat konkrit, individual dan final yang menyatakan bahwa perolehan kembali Kewarganegaraan Indonesia. Heidy Mariska tidak perlu menggunakan prosedur biasa yang telah ditetapkan oleh peraturan berundang-undangan. Hal ini dikarenakan kehilangan Kewarganegaraan Indonesia yang dimiliki Heidy Mariska akibat ketidakhati-hatian pejabat dalam menerapkan Pasal 17 huruc (c) Undang-Undang No. 62 Tahun 1958.

Sebagai bentuk tanggung jawab negara terhadap hak asasi seseorang yang tercantum dalam konstitusi, yakni Pasal 28 D ayat (4) UUD NRI 145 bahwa status kewarganegaraan adalah hak setiap orang, maka pemulihan kembali status kewarganegaraan Indonesia atas Heidy Mariska harus segera mungkin dilakukan. Keberadaan Heidy Mariska dengan status tanpa kewarganegaraan sangat dibatasi dengan berlakunya Undang-Undang No. 23 Tahun

2006 tentang Administrasi Kependudukan dan Undang-Undang No. 6 Tahun 2011 tentang 
Keimigrasian. Perolehan kembali status Kewarganegaraan Indonesia atas Heidy Mariska berguna untuk sebuah pengkuan bahwa Heidy Mariska dinyatakan sebagai Warga Negara Indonesia yang dikuatkan dengan sebuah dokumen tertulis. Paspor atau Kartu Tanda Penduduk sangat berguna untuk Heidy Mariska sebai perwujudan pemenuhan hak asasi. Paspor atau kartu identintas yang dimiliki Heidy Mariska sebagai Warga Negara Indonesia berguna untuk proses peristiwa kependudukannya. Misalnya, jika Heidy Mariska tetap berkeinginan menjadi Warga Negara Belanda, maka kartu identintas tersebut dapat digunakan Heidy Mariska untuk melakukan permohonan menjadi Warga Negara Belanda.

\section{Daftar Bacaan}

\section{Buku}

Asshiddiqie, Jimly, Hukum Tata Negara Jilid I, Sekretaris Jenderal dan Kepaniteraan Mahkamah Konstitusi, Jakarta, 2006

, Hukum Tata Negara Jilid II, Sekretaris Jenderal dan Kepaniteraan Mahkamah Konstitusi, Jakarta, 2006

\section{-------- , Pilar-Pilar Demokrasi, Konstitusi Press, Jakarta, 2006}

Gautama, Sudargo, Warga Negara dan Orang Asing, Alumni, Bandung, 1997

Hadisoeprapto, Hartono, Pengantar Tata Hukum Indonesia (e-book), Liberty, Yogyakarta

Kansil, C.S.T., Hukum Kewarganegaraan Republik Indonesia, Sinar Grafika, Jakarta, 1992

Marzuki, Peter Mahmud, Penelitian Hukum, Kencana Prenada Media Group, Jakarta, 2005

Manan, Bagir, Perkembangan dan Pengaturan Hak Asasi Manusia di Indonesia, Yayasan Hak Asasi Manusia (e-book), Demokrasi dan Supremasi Hukum, Jakarta, 2001

-------- , Hukum Kewarganegaraan Indonesia dalam UU No. 12 Tahun 2006 (e-book), FH UII Press, Yogyakarta, 2009

MD, Mahfud, Makalah Sosialisasi UU No. 12 Tahun 2006 tentang Kewarganegaraan

Tutik, Titik Triwulan, Konstruksi Hukum Tata Negara Indonesia Pasca Amandemen UUD 1945 (e-book), Kencana Jakarta, 2010

Qamar, Nurul, Hak Asasi Manusia dalam Negara Hukum Demokrasi, Sinar Grafika, Jakarta, 2013 